\title{
Practitioner of the Dismal Science? Who, Me? Couldn't Be!!
}

\section{Citation}

Freeman, Richard B.. 2014. Practitioner of the dismal science? Who, me? Couldn't be! In Eminent Economists II: Their Life and Work Philosophies, edited by Michael Szenberg and Lall B. Ramrattan, 166-186. Cambridge: Cambridge University Press.

\section{Published Version}

doi:10.1017/CB09781139629096.015

\section{Permanent link}

http://nrs.harvard.edu/urn-3:HUL.InstRepos:34330162

\section{Terms of Use}

This article was downloaded from Harvard University's DASH repository, and is made available under the terms and conditions applicable to Open Access Policy Articles, as set forth at http:// nrs.harvard.edu/urn-3:HUL.InstRepos:dash.current.terms-of-use\#OAP

\section{Share Your Story}

The Harvard community has made this article openly available.

Please share how this access benefits you. Submit a story.

Accessibility 


\title{
Practitioner of the Dismal Science? Who, me? Couldn't be!!
}

\author{
Richard B. Freeman
}

Why did I become a labor economist concerned with the institutions that affect the lives of workers and the organization of work when I could have been an investment banker, McKinsey consultant, used car salesman or even a theorist working out the truths of the Invisible Hand on a blackboard in some dark office?

When I was in grade school, I did not dream of becoming an economist. I doubt that any kid does. I was more enthralled with literature - ah to write the great American novel - or with managing a stable of villainous professional wrestlers ala the Grand Wizard, Lou Albano or Classie Freddie Blassie. Those would be fun careers. Economics? Didn't someone call that the dismal science? Who wants to be dismal?

There is an answer to the why economics question that would please the Invisible Hand. This is that at age seventeen I calculated the expected present value of lifetime earnings from economics and other plausible careers and, taking account of my preferences toward work activities, money, and risk, picked the career most likely to produce the highest utility. The Hand would be even happier 
if I told you that I had carefully weighed my abilities and interests - strong but not Putnam Prize level math abilities, strong but not Chekhov level writing abilities, strong but not Nelson Mandela level social concerns - against the payoffs to those abilities/interests in different professions and determined that economics was the best fit.

At some level, Invisible Hand explanations of career choice work as a good first approximation for many of us. In a sample of thousands of young persons choosing careers, I almost surely would be in the set of those who fit economics and not in the set of those who fit pro wrestling (save as a manager or script writer). But I am also sure that many in the suitable-for-economics set chose other occupations - law, literature, investment banking, sociology, and so on. Economic models of individual outcomes invariably have huge residuals that tell us that they miss much about what determines individual choices and payoffs.

The economics of education, for example, lives on the fact that education raises earnings. But regressions of ln earnings on formal education, however measured, explain less than $5 \%$ of the variance in ln earnings. Within each education group, there is a huge dispersion of earnings among observationally equivalent people that dwarfs the variance across the groups. Economics majors 
from Harvard of the same age, gender and race and with similar grades, for instance, will have very different earnings ten or twenty years later. One may end up a six-digit earner while another struggles to keep up with the bills.

In physical science, it is irrelevant which rapidly moving atom interacts with neighboring atoms to equilibrate the level of heat in some closed space or which molecules interact with other molecules to form a chemical compound. The atoms and molecules are identical. But our genes and environment make humans heterogeneous, and we invariably ponder the unique factors or accidents that lead us down one path over another. Unless the cosmologists' hypothesized multiverse is true, there is no way to test any story of how idiosyncratic events affect long term outcomes, and even then it would require traveling to other universes, Dr. Who style. The most we can do is tell a consistent believable story about why we got to where we are.

What set me up to choose economics was Isaac Asimov's Foundation series of science fiction books. ${ }^{1}$ The 1 st volume of the series laid out the key proposition that, Hari Seldon be praised, it was possible to construct a science of history. Equations based on verified knowledge could predict the flow of history - at least up to the point where uncertainty allowed the heroes of the series to gain better 
outcomes for humanity through their brave deeds. The 2nd volume of the series taught the reader that economics dominated military power in determining history. The Foundation expanded through its trading practices. Free trade helped it survive the efforts of the mighty Empire to crush it.

I read the Foundation series in junior high school when I caught the learning bug and spent every free moment devouring any 50 cent paperback on whatever caught my fancy - history, literature, science fiction, Greek culture, religion, philosophy, psychology, astronomy, jazz, mathematics, whatever. It was a mad effort to learn all there was to know about anything and everything. There were no interesting economics books in paperback ${ }^{2}$ to compete with George Gamow or Edith Hamilton, with Asimov and the other science fiction stars, or with Euripides and Sophocles and the Bhagavad-Gita or Chekhov or Scott Fitzgerald. So my first appreciation of social science and the power of economics came from the Foundation series. My guess is that most junior high school devotees of science fiction are entranced by the speculative physical science and go on to careers as inventors, engineers, scientists. What I took away was the notion that the aggregation of individual actions rather than the decisions of kings and queens determined the flow of history and that it was possible at least in the 
far-off future to write down equations that would predict how those actions determined the flow of history. Wow!

In college, I quickly learned that history was not a science; that sociology explored fascinating problems with no clear conceptual framework; and that while experiments made psychology a science its focus on the individual offered no insight into how behavior aggregated to produce historical change. By contrast, economics had the logical structure of science and dealt with micro and aggregate behavior in ways that could illuminate the dynamics of historical development. To understand the broad sweep of history, one had to begin with economics, or so it seemed to me. I bet that Hari Seldon studied economics before writing down the dynamic general equilibrium equations that underlay the Foundation series.

Still, there were aspects of economics that troubled me. Economics lacked the verifiable facts and invariant relations that characterized experimental sciences. It relied too much on abstract principles and too little on careful investigation of actual behavior for my taste. The applied calculus of price theory seemed far removed from business reality, at least as presented in undergraduate micro-theory. If all that was required to run a successful business was to differentiate profits functions, why were managers so highly paid? If they did 
more than that, why we were not taught what they did? When I posed these questions after one particularly tiresome class, the answer that there was a gap between theory and reality did not sit well with me. Science is supposed to fit reality. Why didn't economists start filling in the reality instead of fussing with indifference curves and tangent lines and, even worse, Edgeworth-Bowley boxes? Wouldn't it be better to learn the calculus stuff fast and spend the rest of the time trying to understand the real world?

In grad school I read Samuelson's Foundations and loved it. That was the way to teach economic theory. But I wanted more from economics than the mathematics of optimization. I wanted economics to answer the big Hari Seldon questions. What leads some societies to succeed and others to fail? Can a society organized around the interactions of ordinary folk (the Foundation) defeat a totalitarian juggernaut run from on high (the Empire)? That was a real issue in the 1960s and 1970s when the Soviet economy seemed to grow faster than the US economy (few realized how inefficient the Soviet system was or that the service sector rather than heavy manufacturing was the economic future). By allocating resources through central planning the Soviets had developed an advanced military technology that risked blowing us all up. 
One of the supposed advantages of the Soviet system was that the state could order young people to go into engineering and science and work on projects the state deemed in the national interest while the US let immature young people like me freely choose careers of lesser import, such as economics. Did this mean that the Soviets would ultimately surpass us? Or was the market analysis right that allowing individuals to choose careers freely gave better outcomes? The issue of whether enough young Americans study science and engineering to maintain the country's technological and economic success has resurfaced several times since then. In the mid 2000s it produced a spate of reports calling for more science and engineering of which the National Academy of Sciences' Gathering Storm attracted most attention. ${ }^{3}$ What I didn't know when I was choosing a career was that the National Science Foundation counts economics as a genuine science. But before that goes to your head, fellow followers of the Invisible Hand, the NSF counts sociology also!

In grad school, I looked for the branch of economics that would best help me address the "really big" questions. Initially, economic development seemed to fit the bill. Understand why country A grows and country B does not and you would be on the way to fulfilling the Hari Seldon vision. If, as a byproduct, that 
meant great trips to exciting places where one would meet exotic women and learn things that were not chalk marks on a blackboard, so much the better. I arrived at Harvard with the vague idea of using Bellman dynamic programming and Markov chains to develop a Seldon-esque growth model but in my first year I took Simon Kuznets' course in development and - squash! - realized how little I knew and how silly it was to try to model something about which you knew little. There were presumably many things that determined whether a country managed to attain a successful development path like Korea or floundered like most developing countries but not much hard knowledge about what those things were. The balanced growth models that were the rage at the time were too far removed from the evidence to be useful. Kuznets bemoaned in class that he could not understand why theorists built such models when the essence of development was unbalanced growth. Kuznets was a great antidote to theory without evidence.

What I took away from this experience was that the "big questions" were too hard to attack directly. One had to come at them from a base of real knowledge, which meant from applied microeconomics where data related to actual behavior in market settings. If the interactions of millions of people determined the future then we should study the behavior of those people - how 
they responded to economic stimuli and how their responses generated new stimuli. Labor economics came closest to trying to do this. It sought to understand the behavior of workers and firms inductively from observation and data rather than deductively from maximizing models. As a bonus, it dealt with unions and social movements that could affect society and the flow of history outside of economic markets. I decided that the road to understanding development and the big questions of history ran through labor.

My undergraduate professor at Dartmouth, Martin Segal, a refugee from the Nazi conquest of Poland, had primed me toward labor. Segal's great gift was thinking about economic behavior. Instead of belaboring income and substitution effects or ways to identify parameters in regression models, he continually asked, what behavior do you think generated that empirical regularity? Does that behavior make sense to you? Long before behavioral economics burst on the scene this had a big impact on my thinking.

At Harvard, John Dunlop focused more on how institutions acted in the labor market. He held economic analyses against a two fold sieve: first, its consistency with data and second, whether it squared with what practitioners said about their behavior. Dunlop wanted graduate students to find their topics from 
the world. When I came into his office with the start of a thesis - a critical assessment of what the literature said on career choice issues - he made as if to tear it up. "OK, now that you've got that literature review BS out of your system, how about doing something real? Think your own thoughts. Get some data. Find something new. Research reality, not old economics papers." Having spent two years reading economics literature ad nauseum for my generals, the idea of analyzing new data to find something new about the world sounded good.

What cemented my choosing labor was Gary Becker's Human Capital. ${ }^{4}$ Pre the human capital revolution, labor economics was largely descriptive and institutional, more concerned with explaining why economics fell short than with making economics work. Reading Human Capital showed that it did not have to be that way. The book treated labor decisions from the perspective of rational choice and sought price theoretic explanations of facts that made price theory a live tool in ways that my undergraduate price theory course had failed to do. Becker had a big vision - not quite Hari Seldon but in the Seldon spirit - that micro-economic thinking offered insight into all sorts of behavior - from going to school to allocating time among multiple activities, to marriage, fertility, interest group politics, crime - topics that had previously been owned by sociology or 
demography or political science. This had an empowering liberating impact on what labor economists could do. It legitimized the range of topics on which I would work in ensuing years.

The human capital optimizing view of labor markets does not explain as much of actual behavior as I and I imagine many others hoped it would do. Behavioral economics, experimental economics, and, most recently, neuroeconomics have shown that optimizing rationality is not always the dominant factor in what we do, even in narrow economic decisions. But even so, the profits constraint that determines whether firms survive or not and that limits what consumers can buy enforces something close to efficient Invisible Hand outcomes even when firms and people make decisions irrationally, for instance by random choice (Becker, again!)5. The implication is that market models based on rational optimization are the natural starting point for any empirical investigation in labor or economics more broadly. They give the first term in a Taylor Series expansion around reality. If the data reject that perspective, then it is up to us to modify the theory and extend the approximation to more terms. If it turns out that some other form of behavior is the first term in the approximation, you still cannot ignore the neo-classical economics, for it will surely be the second or third term. 
My thesis was on career choice, with a special focus on science and engineering. I was struck with the paucity of evidence for what I took to be one of the main propositions of the human capital model - that investments in career skills by young persons responded substantially to the returns to those skills. Running ln earnings equations and interpreting the coefficients on years of schooling as returns to schooling, as was prevalent in the literature, did not directly test supply or demand behavior. I felt I had some insights into career choice, being recently in that game myself and I knew that I could go beyond introspection and survey other students about what they knew and were thinking as they made their choices. Last but not least, studying career choice would allow me to determine if an economy where young persons made choices freely could compete in science and engineering with a society where central planners determined how many students went into what fields. A well-identified estimate of the elasticity of the supply of students to different fields would go a long way to resolving the larger question.

Examining data on the fields of study of chosen by students, I discovered that first year enrollments in engineering fluctuated with starting salaries from college placement offices. When starting salaries went up, the proportion of 
students choosing engineering went up. When four to five years later students from a large entering class graduated with engineering degrees, the large number of graduates drove salaries down. The fluctuations in the data suggested a classic cobweb cycle. Ted Schultz warned me that all I really had with engineers was one cycle driven in large part by the post-Sputnik increase in demand for engineers. Maybe, he suggested half-joking, I should wait a decade or so for some more observations before I called this. With more data, there was also the potential of building a more sophisticated model. But whereas a tenured professor like Schultz could wait for another cycle or so, a new $\mathrm{PhD}$ couldn't, so I proceeded to publish my thesis work. ${ }^{6}$

What made me confident that I had the basic story right - that supply was quite elastic to economic opportunity - was that my survey of students showed that they were reasonably informed about pay and employment opportunities, paid attention to salaries on the margin, knew something about the life cycle pattern of earnings in different fields, and so on. Yoram Ben-Porath suggested that I probe the link between starting salaries and expected lifetime earnings and the relevance of rational expectations to the cycles in a more structured model. Perhaps I should have followed his advice but I didn't. Discovering the basic 
patterns and finding a simple parsimonious story was great fun. I was uneasy about pushing weak data too far into a particular framework. What I did instead was to carry the analysis to other fields where one's major was closely linked to one's occupation, such as physics, and was reassured to find that supply looked elastic in enough areas that the pattern was not a fluke. ${ }^{7}$

Since then I have worked on a host of labor issues - from unions to crime to modes of compensation to labor standards to discrimination to labormanagement relations to welfare states, etc; and have studied labor markets in Asia (Korea, Australia, China, Japan, Sri Lanka), Europe (Sweden, Ireland, Germany, the UK, Spain, Norway, Poland); Latin America (Argentina, Dominican Republic, Venezuela, Columbia, Peru, Chile); and Africa (South Africa). Recently, I have returned to studying the science and engineering work force, though now in the context of globalization and with greater attention to the demand side of the market, as I will describe later. Someone looking at my portfolio of topics might wonder if I was a mad hatter, caught up with wanderlust, a jet setter seeking thrills in world hot spots, a secret agent for the CIA or M5, or a fugitive from the police. Every once in a while I get suspicious looks from immigration officials at airports, but I just say professor of economics and that establishes that I 
am harmless (if they only knew the trouble we can cause, at least when we are defunct!)

Let me explain what motivated some of the topics and mode of research.

The second area on which I worked in depth was black-white economic differences. What grabbed my attention was that just as economists were modeling discriminatory differences as an equilibrium process resulting from statistical discrimination or from the Becker model of how fixed prejudicial tastes produced segregation or income differences in competitive markets, young blacks were making unprecedented gains in earnings and occupational status. The sudden rise in relative black incomes after the 1964 Civil Rights Act could not possibly result from gradual changes in tastes or in statistical discrimination. Shades of Kuznets, why were theorists modeling equilibrium when the data pointed to change? Examining CPS and Census figures on black and white earnings and occupational attainment I found that the post-1964 gains occurred largely among young college educated workers and were greatest in the South. Visiting the historically black colleges, most of whose graduates had gone into teaching and public service I learned that before the Act virtually no US corporation recruited at those colleges, whereas after the Act, corporations came to recruit in droves. In 
response, students were shifting rapidly from teaching and social work into business majors. My interpretation was that the change in the law was driving demand along an elastic supply curve. ${ }^{8}$

That the Civil Rights Act was the main exogenous factor raising demand was controversial. Some analysts argued that the late 1960s boom caused the shift in demand. Others said that the increased salaries for new graduates reflected their choosing high wage/low investment jobs. Others argued that the gains in wages reflected increased welfare rolls, which reduced the supply of black workers. Many on the left objected to my optimistic reading of the decline in discriminatory income differences: why did I stress that the glass was half full when it was half empty? My response was that it was filling up from all empty before.

If government actions were important in reducing discrimination, perhaps government actions had also been important in maintaining black-white differences in the years following Emancipation. Examining the historical data, I found that government actions - the discriminatory behavior of southern states had played a huge role in preventing black Americans from advancing in the labor market for decades. I read Horace Mann Bond and histories of Southern states that 
documented the discriminatory policies and legal and illegal efforts to prevent blacks from investing in skills and advancing in the job market. One of the biggest mistakes of my career was that, wanting and failing to develop a purely economic theory of why poor whites aligned with wealthy whites rather than with poor blacks in Reconstruction days when both seemed possible, I never brought that historical work to completion.

Ensuing studies have confirmed the view that government policy sparked the increased demand for black workers. Where I was wrong was to think that the rise in black incomes was going to continue smoothly to equalize incomes with whites save for differences in background factors, which invariably would take a long time to work out. While black college graduates were advancing into better jobs, young less educated black men were having greater problems in the job market. ${ }^{9}$ An increasing number were involved in crime and ended up spending years incarcerated. My interest in the economics of crime came from realizing that crime was a major part of the poverty problem facing black Americans. The US could not cure poverty unless it cured the crime problem and conversely. Curing crime, in turn, required that we understand the supply behavior of young black 
men living in the inner city. So how did they go about making their career decisions?

To find out I developed the NBER Inner City Youth Survey that focused on illuminating how young inner city men saw the risks and rewards to crime compared to the opportunities, or lack thereof, of employment and earnings in the legitimate economy. ${ }^{10}$ One of the lessons from studying youth crime is that the line between legitimate work and crime is porous. Youths shift back and forth depending on opportunities. Later I realized also that excluding the huge proportion of young American men in jail or prison from measures of joblessness exaggerated the success of the US job market compared to European job markets in providing gainful employment. This pleased Brussels but not Washington.

Perhaps my best-known work has been on unions. But for the much of my career I stayed away from unions and other traditional labor issues such as minimum wages or hours worked. I was new wave, not old stuff; the market for physicists or post-docs, not for machinists or automobile workers (strangely, the United Automobile Workers has organized more post-docs and graduate students than any other union). I had good reason to stay away from unions. My thesis advisor Dunlop knew more about them than anyone else. In the 1940s he had 
modeled unions as optimizing organizations with little success. ${ }^{11}$ He spent much of his ensuing career cumulating knowledge about particular unions, employers and markets to be able to make labor relations work better in the country. At Chicago, my mentor on the senior faculty was Gregg Lewis, who took the Kuznets approach to unionism - measuring union wage effects with a skill and care that is a model to labor economists to this day. Milton Friedman interpreted the estimated union wage effects as implying that unions increased inequality by creating differences among similar workers.

I had no intention of working this terrain until, preparing a paper for an AEA session on Albert Hirschman's Exit, Voice, and Loyalty ${ }^{12}$, an idea came into my head about how to use the exitvoice dichotomy to study unions and turn Hirschman's analysis from a broad framework for thinking about political vs market responses to problems into a testable model of behavior. Unions were collective voice. This meant they should reduce quits via the exitvoice tradeoff and should provide information to firms about worker preferences that would affect many parts of the labor contract, which in turn would lead firms to change their labor practices. Unions were institutions that affected the entire workplace, not just pay. ${ }^{13}$ 
Suddenly there seemed to be lots of things to study about unions with then newly available large computerized data sets on workers and establishments. Ensuing work by me and others at Harvard and NBER quantified the impacts of unions in the private sector on economic outcomes such as the composition of compensation, the dispersion of pay within firms, productivity, profits, age or experience earnings profiles, layoffs, capital-labor substitution, and extended the analysis of the union wage effect to examine how it varied with the union share of a market. In 1984, after five or so years working this topic, I summarized (with James Medoff) the findings in What do Unions Do - a book that owes much to the editor of Basic Books, Martin Kessler, who kept pushing for clarity and social significance. ${ }^{14}$ The bottom line of quantifying the "two faces of unionism" - voice and monopoly - was a relatively favorable assessment of unions: the voice impact of the institution had greater social effects than the monopoly impact. Unions reduced inequality by compressing wages within workplaces and by shrinking the pay gap between white collar and managerial workers and production workers. Unions raised savings through negotiated pension programs, and so on.

Fast-forward twenty years. In the early 2000s Bruce Kauffman and James Bennett invited some 25 labor researchers to a twenty year retrospective 
assessment of the findings of What Do Unions Do? or WDUD as they acronymized it. Post the book I had stayed away from further investigating what unions did in the private sector. I worked on unions to the public sector, where they operated in a very different economic environment, on union developments in other countries, and on the continued decline of union density. ${ }^{15}$ I did not want to play Ibsen's Master Builder in defending the book against scholarly work from the next generation of researchers. Nor did I want to fall into the cognitive dissonance trap of trying to spin new evidence as if it confirmed the book when it really didn't. It was up to others, less intimately involved with the work and more dispassionate, to judge whether its findings did or did not stand up over time.

The twenty-year review was one of the scarier times of my professional career. I had paid enough attention to ensuing work to know that there was no devastating repudiation of WDUD but maybe when all the experts came together it was going to be "run for cover/hide your head" time. I was nervous at the session at the Meetings on the book and at the papers as they appeared in one edition after another of the Journal of Labor Research over a two year period. I worried if the DUD in the acronym was a harbinger of what the twenty year retrospective would conclude. Let me be clear, this was not some festschrift 
nonsense. The reviews were hardnosed analyses by researchers who with the passage of time had more evidence, improved econometric techniques, and more knowledge on which to draw than went into the book. Some researchers viewed unions less favorably than I did and disagreed with the conclusion that voice effects dominated monopoly effects. At the minimum, they would find any flaws that they could. I was sufficiently frazzled that my paper at the event "What Do Unions Do?: The 2004 M-Brane Stringtwister Edition“ must be the only economics paper where string theory and Calibi-Yau space play a major role, though not as a geometry for general equilibrium but as a place in the multiverse to hide if I had to face being wrong, wrong, wrong.

When all was said and done the assessors were critical but fair and the scary event turned out to be more confirmatory of the work than I had imagined beforehand. The general consensus of the reviews, now a published book far larger than the original (Kauffman and Bennett, 2007),${ }^{16}$ was that WDUD got most things right. The last chapter of WDUD had highlighted the on-going decline in union density, a topic on which I continued to work, and that was what generated the most controversy. Arguments over why union density had been falling in the private sector aside, Barry Hirsch had the comment that struck me as the most 
telling, "Freeman and Medoff got right what unions did when there were still unions to do it." With just 7.5\% of private sector workers organized in 2007 (compared to some $40 \%$ organized in the mid-1950s and $20 \%$ in the 1970 s), most labor specialists have come to believe that unions are past history and that studies of unions are an exercise in paleontology or pathology.

I disagree with that view. I disagree because a larger proportion of the US work force today says it wants unions or some other worker-based organization to represent them than ever before. The Workplace Representation and Participation survey that I conducted with Joel Rogers in the mid 1990s and ensuing surveys document this desire and delineate the types of organizations that workers want as well as surveys can. ${ }^{17}$ Some workers want traditional collective bargaining. Others want committees to meet and discuss workplace issues with management.

Confirming the hunger for representation revealed in the surveys, as of 2008 some two million workers had joined the AFL-CIO's non-collective bargaining affiliate organization, Working America, even though it does not help workers at their workplace. They joined in the hope that this organization could influence the direction of labor practices and policies in the country. 
In a free market, it is hard to believe that the desire for representation will go unmet ad finitum. At the same time, strong management opposition to collective bargaining makes it hard to imagine that the labor relations system that developed under the depression era National Labor Relations Act can deliver what workers want. Something will have to give.

Pondering this problem and studying innovative union responses to the Internet and modern information technology suggests that workers need a new union form. In the early 2000s, Rogers and I laid out the framework for such a form, which we labeled open source unionism. ${ }^{18}$ The open source vision is of a union movement that is more voice than monopoly, that relies on local community support more than strikes to pressure employers, and that delivers services to workers inexpensively over the Internet. To see such a new union form grow and fill the gap between worker desires for representation and what they have would give me an incredible high, but so far only Working America has managed to sign up large numbers of workers into anything that approaches a new organizational form, and it is unclear what it will do with and for them. As a tenured professor, I can follow Ted Schultz's suggestion years ago and wait and see 
but as age creeps up, I can't wait too long. Come on, guys, innovate, make open source unionism work.

During the two decades between WDUD and the retrospective on WDUD, my interest in labor institutions shifted from the US to the rest of the world. I realized that calling the book What do Unions do was misleading, for the book examined what unions did in the US while ignoring the rest of the world. Looking at labor markets in other countries it was clear that one could not study unions in isolation. They were part of the institutional framework that differentiated EU countries from the US. The key question for analysis mimicked the question that drove work on US unions: what did labor institutions do to national economic outcomes - in particular, the extent to which, if at all, they explained the lower dispersion of earnings and incomes in the EU than in the US and the higher employment rates in the US than in the EU.

I was uneasy about generalizing from institutional differences to differences in economic outcomes. In graduate school, Dunlop had told the story of Cantillon's cock (which I believe he learned from John Hicks). Every morning the cock awakens moments before sunrise and does what nature has programmed it to do: let out a mighty "cock-a-doodle-doo". Observing the time sequence of 
cause and effect, the cock concludes that crowing induces the sun to rise. So too, warned Dunlop, might union leaders, business, and government officials believe that what they say or do determines economic success when in fact market forces were truly at work. To find out what impact institutions have on economic outcomes requires that we measure the extent to which institutional rules are enforced or implemented, and then quantify their effects, one outcome at a time, using the best empirical tools at our disposal.

Comparisons of aggregate outcomes among countries with different levels of collective bargaining coverage and broad indicators of labor market regulations offer one way to gain some insight in what labor institutions do, but no labor economist puts much faith in such aggregated data. Measures of institutions across countries are weak, there are many unmeasured factors and possible interactions of institutions, and there are few data points in most cross-country analyses. A preferable way to learn about how institutions affect outcomes is through microeconomic analysis of individuals or firms, comparing those affected by particular institutions and those not affected, ideally with some form of difference in difference model. Realizing that there were far too many countries and institutions for me to master, I organized the NBER Comparative Labor project 
and called for help from my colleagues. We produced five NBER volumes with detailed studies by dozens of researchers focused on differences between the US and EU labor markets. ${ }^{19}$ The project leaders summarized the findings in their volumes in Working Under Different Rules. ${ }^{20}$ The NBER labor group has also compared the US and Canadian labor markets, studied the welfare state in Sweden, examined the British economy in the 2000s, and investigated youth labor markets in diverse advanced countries. ${ }^{21}$ The work highlights the payoff from teamwork and collaboration in research, both among NBER researchers and with researcher in other countries. I would extend Newton's famous statement about "standing on the shoulders of giants" to include the shoulders of our colleagues and peers. We see further because we are part of a collective cooperative (and competitive) research enterprise.

The diverse empirical studies in the Comparative Labor Market program notwithstanding, I realized that if I was to truly grasp how European labor institutions operated, I had to get some first-hand experience and observation of those institutions. I made that case to Harvard and convinced the University to allow me to spend the better part of five years in Europe, where I worked at the Centre of Economic Performance at the LSE and interacted frequently with 
business, labor, government people and economists throughout the continent on labor practices and issues. Paris today. Northern Italy tomorrow. Stockholm next week. Then Copenhagen and Amsterdam. Nice work if you can get it. Locales aside, talking with decision-makers taught me a lot about country labor practices and operating procedures. How else could I have truly come to appreciate that a social partner is not someone you spin around the dance floor but a union organization or employer federation that participates in determining policies? Advanced Europe is Hirschman's voice mechanism writ large.

The major conclusion that I draw from this work is that labor institutions have a first order effect in compressing the distribution of earnings, but have only modest and difficult-to-discern second order impacts on economic efficiency. It may be that there is more Coase-style efficient bargaining in the world than labor economists have generally realized. But until we have a detailed analysis of the bargaining process and understand how the Europeans do their social dialoguing, that is just an interpretation.

Another promising way to research the impact of institution on economic outcomes is, seemingly paradoxically, to forget about countries and to study companies. For this the US is particularly valuable because absent centralized 
collective bargaining and strong labor regulations, US firms organize work and compensate employees in very different ways, with possible consequences for economic performance and worker well-being. The vastly greater number of firms than countries and greater possibility of finding pseudo-experimental variation in practices across firms than among countries also argued for analyses of labor institutions at the level of firms. My work here, with Doug Kruse and Joseph Blasi, focused on "shared capitalist" modes of compensation - those that link worker pay to company or group performance - and associated methods of devolving some work decisions from management to workers. For years, Kruse and Blasi had studied employee owned and profit-sharing firms, which most economists, myself included, viewed as an interesting but a not-very important niche part of the economy (think plywood producers in the Pacific Northwest, a few high tech start-ups in Silicon Valley, and of course the famous Lincoln Electric). The predominant theory of the firm held that basic economic forces dictated that management retain residual control of assets and decisions and that group incentive systems would fail due to the free rider problem arising from the fact that workers gain only a modest fraction of the rewards of their effort. 
But could it be that Kruse and Blasi were studying a more important phenomenon than the rest of us recognized? In 2000 I set up an NBER project with Kruse and Blasi to find out. We added questions about shared capitalism to the General Social Survey and found that nearly half of the US work force received part of their pay as group incentive. Shared capitalism in the US was rarely full employee ownership ala the Mondragon conglomerate in the Basque country nor pure profit-sharing but it was part of the mix of compensation in many firms. Assisted by the managements of some large multinationals and some smaller enterprises, we conducted a largely Web-based survey of over 40,000 workers covered by different plans and found that worker co-monitoring was an important force in fighting the incentive to free ride. Workers covered by group incentive pay were more likely to act against shirkers than workers paid in other ways. We also found that shared capitalism gave better outcomes for workers and firms when management combined it with complementary labor policies and practices, which might reflect some underlying latent variable such as the corporate culture that business folk and business school profs sometimes invoked to explain differences in corporate performances. ${ }^{22}$ 
My great failure in these investigations of institutions across countries and firms is in combining what I learned into a broad theoretic framework for understanding the interface between institutions and markets. Sometimes I think that I have learned too much about specific institutions to see how they fit together into a single theory. Good theories often come from knowing just enough to see the forest but not the trees. Alfred Russell Wallace knew less about biological variation than Darwin but was first off the gun with the theory of evolution, which galvanized Darwin to put some of his knowledge into On the Origin of Species. Coming to biology after a history degree, Robert Trivers developed his analyses of reciprocal altruism and parental-child conflict without the knowledge of senior specialists in evolutionary theory. If my memory deteriorates with age, perhaps I will forget enough to see the forest of market and institutional forces taken together.

But at other times I think that what analysis of institutions needs is more and different knowledge - knowledge of advanced mathematics to help guide thinking from the particulars of institutions to a deeper abstract structure. But what math might do the trick - algebraic geometry? representation theory? non equilibrium statistical mechanics? functional analysis? combinatrics? PDEs? Calibi- 
Yau space and differential geometry? Come on, theorists in dark rooms with blackboards and mathematicians seeking new fields to conquer, try some abstractions with economic institutions. We need them.

One other topic that has attracted my attention and that of virtually every economist concerned with real economic problems. Like taxes and death, you cannot escape globalization. My work on globalization has focused on three issues. The first is global labor standards, which I have approached from the perspective of consumer choice - the willingness of consumers to pay more for goods made under good conditions than bad conditions - rather than from the view, favored by some trade economists, that standards are protectionism in disguise. My work with Kimberly Elliot demonstrates further that globalization and labor standards are complementary rather than antithetical developments, contrary to the fear of many on the left that globalization forces firms to reduce standards. ${ }^{23}$ What makes the market for standards unique is that the entrepreneurs are human rights activists who galvanize consumer sentiment to pressure firms to improve conditions to avoid losing sales.

The second issue, which has become common wisdom in discussions of globalization and labor, is that globalization's big impact on labor around the 
world began when China, India, and the ex-Soviet bloc (all of whom had previously operated as autarkies) joined the global capitalist system in the 1990s. These countries brought lots of low skilled labor and little useful capital to the world economy, which effectively doubled the size of the global work force. The ensuing reduction in the capital/labor ratio underlies, I claimed, most of the impacts of globalization on labor: the shift in bargaining power toward capital, the changing patterns of trade and foreign direct investment, and the off shoring of work. This is a case of seeing the forest because you haven't studied the trees.

The third issue, which occupies my research today, has a Hari Seldon quality to it. This is the impact of the spread of university education and knowledge around the world on economic development and in particular on the growth of useful knowledge. Technologists such as Ray Kurzweil argue that the increased power of computers will accelerate our control over nature, producing a "singularity" in history. ${ }^{24}$ Without gainsaying the gigabytes of computing power, I stress the growing number of science and engineering specialists around the world. With more highly educated science and engineering specialists today than in all previous times taken together, connected through the Internet, and, yes, with access to powerful computers, we have the potential for a singularity-type 
explosion of useful knowledge that could go a long way to solving the great problems we face in the areas of climate change, energy, pressures on natural resources (water, food, minerals, metals), disease and illness and so on.

Turning that potential into reality is an economics problem of the first magnitude in allocating and managing human resources. Given the uncertainty of research, the political economy of the allocation of budgets, and problems in evaluating the benefits of public goods like knowledge, decision-makers have no easy maximize-the-net benefit function to guide them, and can and have made some costly mistakes. Between 1998 and 2003 the US doubled the budget for the National Institute of Health and then proceeded to cut the budget in real terms, which created a crisis in the careers of many of the new researchers induced into bio-medical research during the boom period - the risky and transformative research that scientists believe is in short supply. Working with the science policy community has convinced me that economics can contribute substantially to helping decision-makers in the government and in firms make better decisions about funding and deploying the great brainpower at humanity's disposal for solving the world's great problems. 
So, what does all this work add up to - a bang or a whimper? It has not yielded a theory of history based on scientific verities. Hari Seldon ${ }^{25}$ still lives far in the future. I like to think that it has provided partial answers to some manageable questions and clues toward the big questions. But even if it only produces partial answers and clues, economics research does not end with a whimper. What economists learn and say - the way we think about problems can and does influence human affairs. And as economics continues to become more empirical and scientific and less dependent on theory without evidence, it will almost surely become more important. Today we have more ways to find how the world works - from lab and field experiments to behavioral economics to the simulations of computational economics to the brain scans of neuro-economics to econometric methodology to administrative and survey data on thousands of firms and hundreds of thousands of workers in dozens of countries, longitudinal as well as cross-section that was unimaginable when I was a graduate student. The next decade of research looks to be so much fun and promising and productive that I envy the newest generation of researchers. I wish I could start anew with you.

Sam Beckett ends The Unnamable with “Where I am I don't know, I’ll never know, in the silence you don't know, you must go on, I can't go on, I'll go 
on." Economists don't know the answers to Hari Seldon future- of-history questions. Perhaps we'll never know them. But moving toward answers through smaller manageable questions, creating and analyzing data, interacting with the practitioners in the world whose behavior we study (workers, union leaders, business leaders, scientists, engineers, whoever) is not dismal science. No way. It is fun - more fun, as best I can tell, than making money as an investment banker, McKinsey consultant, or used car salesman, or eve than theorizing on a blackboard in some dark office. And it is more important. With apologies to Beckett, I feel more strongly than when I began that we can and will break the silence of not knowing. I intend to go on searching for answers to the questions that seem important. I hope you will do the same. May your new research and mine illuminate important social phenomenon and justify all that fun to the world.

1 For a detailed discussion of the series see http://en.wikipedia.org/wiki/The_Foundation_Series

2 There was one paperback nominally on economics, by George Soule, who was actually a technologist. 
${ }^{3}$ National Academies. 2007 Rising above the gathering storm: Energizing and employing America for a brighter economic future. Committee on Prospering in the Global Economy of the Twenty-first Century, Washington, DC. My response to the furore over the number of science and engineering graduates is given in Richard Freeman, Investing in the Best and Brightest: Increased Fellowship Support for American Scientists and Engineers http://www.brookings.edu/papers/2006/12technology_freeman.aspx

${ }^{4}$ This is currently in its 3rd edition. Gary Stanley Becker, Human Capital: A Theoretical and Empirical Analysis, with Special Reference to Education, (University of Chicago Press, 1993).

${ }^{5}$ Becker, Gary “ Irrational Behavior and Economic Theory” The Journal of Political Economy, Vol. 70, No. 1 (Feb., 1962), 1-13

${ }^{6}$ Freeman, Richard, The Market for College Trained Manpower. Harvard University Press, 1971. "A Cobweb Model of the Supply and Starting Salary of New Engineers,” Industrial Labor Relations Review 29:2, January 1976, 236-48.

7 Freeman, "Supply and Salary Adjustments to the Changing Science Manpower Market: Physics, 1948-1975," American Economic Review 65(1): 27-39 (March 1975). "Employment Opportunities in the Doctorate Manpower Market," 
Industrial Labor Relations Review 33:2, January 1980. "Legal Cobwebs: A Recursive Model of the Market for Lawyers," Review of Economics and Statistics May 1975.

${ }^{8}$ Freeman, "Changes in the Labor Market for Black Americans," Brookings Papers, Summer 1973, "Decline of Labor Market Discrimination and Economic Analysis," American Economic Review 63:2 (May 1973),280-6. The Black Elite: The New Market for Highly Educated Black Americans, (McGraw Hill, 1976).

${ }^{9}$ What Went Wrong? The Erosion of the Relative Earnings and Employment among Young Black Men in the 1980s" with John Bound, Quarterly Journal of Economics CVII:1, February, 1992, 201-232

${ }^{10}$ Harry Holzer ed., The Black Youth Employment Crisis. with, NBER Conference Volume, (University of Chicago Press, 1986.) "Why Do So Many Young American Men Commit Crimes and What Might We Do About It?", Journal of Economic Perspectives 10:1; 25-42 (Winter 1996). "Crime and the Employment of Disadvantaged Youths", in Urban Labor Markets and Job Opportunity, by George Peterson and Wayne Vroman, eds., (Washington, DC: Urban Institute Press, 1992). 
${ }^{11}$ Dunlop, John, Wage Determination Under Trade Unions, (Macmillan Company, New York. 1944).

12 Albert O. Hirschman, Exit, Voice, and Loyalty: Responses to Decline in Firms, Organizations, and States, (Harvard University Press, 1970)

13 Freeman, Richard Individual Mobility and Union Voice in the Labor Market," American EconomicReview May 1976, 66(2): 361-68.

${ }^{14}$ Freeman and Medoff, What do Unions Do?, (Basic Books, 1984).

${ }^{15}$ On the public sector, Freeman, when Freeman and Ichniowski, When Public Sector Workers Unionize, (University of Chicago Press for NBER, 1988). "Unionism Comes to the Public Sector," Journal of Economic Literature 24 (March 1986): "Contraction and Expansion: The Divergence of Private and Public Sector Unionism in the United States", Journal of Economic Perspectives. Spring 1988, 2(2): 63-68. On unions outside the US, “The Impact of Industrial Labor Legislation on Union Density in the U.K., 1945-1986", with Jeffrey Pelletier, British Journal of Industrial Relations 28:2, July 1990. "Crumbling Pillar? Declining Union Density in Japan" with Marcus Rebick, in Journal of the Japanese and International Economies, 1990, 578-605; "The Changing Status of Unionism Around the World", in Wei-Chiao Huang (ed) Organized Labor at the 
Crossroads, (Michigan: Upjohn Institute for Employment Research, 1989). "Unionism in the U.S. and Other OECD Countries" with David G. Blanchflower, Industrial Relations 31:1 (Winter 1992), 56-79. On the decline of unions, "Why Are Unions Faring Poorly in NLRB Representation Elections?" in Tom Kochan (ed), Challenges And Choices Facing American Labor, (Cambridge: MIT Press, 1985). "The Effect of the Union Wage Differential on Management Opposition and Union Organizing Success" American Economic Review. AEA Papers and Proceedings May 1986, 76(2): 92-96. "Employer Behavior in the Face of Union Organizing Drives", with Morris Kleiner, Industrial and Labor Relations Review 43:4 (April, 1990), 351-365.

${ }^{16}$ James T. Bennett and Bruce E. Kaufman, What do Unions do?: A Twenty-year Perspective, (Transaction Publishers, 2007).

${ }_{17}$ Richard Barry Freeman and Joel Rogers, What Workers Want, (Cornell University Press, 1999, 2nd edition 2006).

${ }^{18}$ Freeman, Richard B and J. Rogers, 'Open Source Unionism: Beyond Exclusive Collective Bargaining.' WorkingUSA: The Journal of Labor and Society 6, no. 2 (2002), "A Proposal to American Labor" - The Nation, June 6, 2002, available on 
the Web in various places, including the website of the famous International Workers of the World, or "Wobblies" famous in American labor history.

19 These volumes are: David Card and Richard B. Freeman, eds., Small Differences That Matter: Labor Markets and Income Maintenance in Canada and the United States (1993); Rebecca M. Blank, ed., Social Protection vs. Economic Flexibility Is There a Tradeoff? (1994) ; Lisa M. Lynch ed., Training and the Private Sector : International Comparisons (1994); Joel Rogers and Wolfang Streeck, eds., Works Councils Consultation, Representation, and Cooperation in Industrial Relations 1995) Richard B. Freeman and Lawrence F. Katz, eds., Differences and Changes in Wage Structures, 1995

${ }^{20}$ Richard Freeman Working Under Different Rules, (Russell Sage Foundation, 1994). 21 Richard B. Freeman, Robert H. Topel, and Birgitta Swedenborg, eds., The Welfare State in Transition 1997 Reforming the Swedish Model; David G. Blanchflower and Richard B. Freeman, eds., Youth Employment and Joblessness in Advanced Countries 2000; David Card, Richard Blundell, and Richard B. Freeman Seeking a Premier Economy The Economic Effects of British Economic Reforms, 1980-2000, 2004; Edward P. Lazear and Kathryn L. Shaw The Structure of Wages An International Comparison, 2008 
22 The research for this has appeared in NBER Working papers but the book is not yet out. Check the NBER site for working papers in July and August 2008 and you will find a bunch of papers by Blasi, Kruse, me, and others who were involved in this project.

${ }^{23}$ Kimberly An Elliott and Richard B Freeman, Can Labor Standards Improve Under Globalization?, (Peterson Institute, 2003).

${ }^{24}$ http://en.wikipedia.org/wiki/Technological_singularity

${ }^{25}$ http://en.wikipedia.org/wiki/Hari-Seldon 